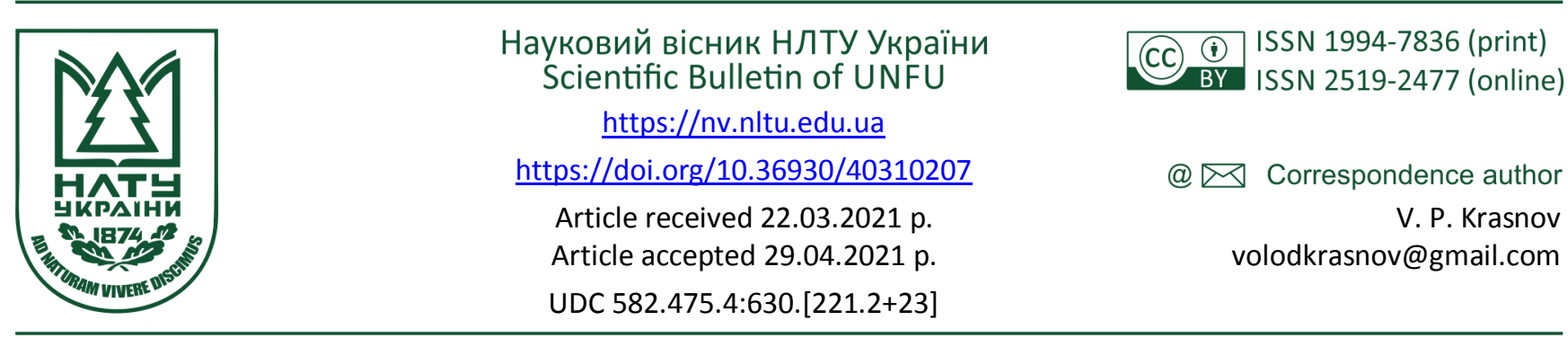

О. В. Жуковський 1 , В. П. Краснов

${ }^{I}$ Поліський філіал Украйнського науково-дослідного інституту лісового господарства та агролісомеліораиії ім. Г. М. Висоиького, с. Довжик, Украӥна

2 Державний університет "Житомирська політехніка", м. Житомир, Україна

\title{
ФОРМУВАННЯ СОСНОВОГО ДЕРЕВОСТАНУ ІЗ ЗБЕРЕЖЕНОГО ПІДРОСТУ ПІСЛЯ РУБКИ ГОЛОВНОГО КОРИСТУВАННЯ
}

\begin{abstract}
Дослідження проведено на стаціонарному досліді, який закладено у 1988 р. у стиглому сосновому насаджені з достатньою кількістю (22000 шт. га $\left.{ }^{-1}\right)$ підросту головної породи. На половині дослідної ділянки здійснено суцільну рубку головного користування з використанням валильних машин способом вузьких пасік. Другу частину ділянки розробляли традиційним методом з наступним створенням на ній культур сосни звичайної (Pinus sylvestris L.). Виявлено, що проведення суцільних рубок головного користування з використанням валильних машин способом вузько пасічної заготівлі деревини дає змогу зберегти достатню кількість підросту сосни звичайної для формування продуктивного деревостану. Застосування подібних технологій сприяє також прискорити термін відновлення лісових насаджень, ніж це відбувається способом створення лісових культур (на 5 років). Встановлено, що деревостан, що сформувався з підросту сосни звичайної, має кращі характеристики, ніж лісові культури, створені після вирубування стиглого деревостану: середній діаметр - на $14 \%$, середню висоту - на 18 \%. Водночас, враховуючи різницю між віком штучних і відновлених з підросту деревостанів - 5 років, можна стверджувати, що відзначені відмінності значно менші. Відмінності у рості насаджень виявлено і під час аналізу розподілу дерев за категоріями санітарного стану, якістю та класами Крафта. Так, основна частка дерев належить до III-IV категорій санітарного стану: $65 \%$ - у варіанті із збереженням підросту та $49 \%$ - у варіанті зі створенням соснових культур.
\end{abstract}

Ключові слова: сосна звичайна; діаметр; висота; запас; санітарний стан.

\section{Вступ}

Головною лісотвірною породою Полісся України $є$ сосна звичайна (Pinus sylvestris L.). Завдяки іï невибагливості до грунтових умов та значній пластичності до клімату у регіоні в деяких типах лісорослинних умов зростають достатньо продуктивні природні насадження цієї деревної породи. Окрім цього, знову ж таки, у деяких едатопах (найбільш зволожених або сухих) сосна звичайна продовжує бути едифікаторним компонентом і має важливе біоценотичне та екологічне значення [10]. Відзначені обставини, а також значний діапазон використання деревини сосни звичайної та великий на неї попит спонукали лісівників упродовж останніх 70 років приділяти особливу увагу створенню штучних соснових насаджень. При цьому головною метою було підвищення їх продуктивності. За останні 30-40 років до терміна "високо продуктивні соснові насадження" частіше додають термін "стійкі". Останне було пов'язано з тим, що створені у 50-70-ті роки XX ст. чисті або з невеликою домішкою берези повислої (Betula pendula Roth) соснові насадження вражалися деякими хворобами, 3 яких масового поширення набули кореневі гнилі, що спричиняються грибом коренева губка (Heterobasidion annosum (Fyare) Bref.). Це призводило до зниження інтенсивності їх росту, зрідження та відмирання дерев на різних за розміром площах. Ці обставини підштовхнули дослідників до створення мішаних соснових культур та розроблення наукових основ використання природного поновлення для створення продуктивних і стійких соснових насаджень.

На сьогодні у Поліссі України дослідники відзначають не поодинокі випадки появи деяких шкідників соснових насаджень, які не фіксували раніше. До них потрібно віднести соснового пильщика звичайного (Diprion pini (Linnaeus, 1758), соснового пильщика рудого (Neodiprion sertifer (Geoffroy, 1785), короїда верхівкового (Ips acuminatus (Gyllenhaal, 1827) та деяких інших $[12,18]$. Осередки поширення двох перших видів виявляли у минулому тільки у південних регіонах України (Херсонській, Харківській, Миколаївській областях), а третій вид, незважаючи на певне поширення у регіоні, не створював істотної загрози сосновим насадженням. Дослідники пов'язують процес їх значного поширення у лісах північної частини України із незадовільним станом штучних соснових деревостанів, що пояснюють змінами клімату, посиленням впливу антропогенних чинників, а також недосконалістю технологій створен-

Інформація про авторів:

Жуковський Олег Валерійович, канд. с.-г. наук, наук. співробітник, лабораторія лісівництва. Email: zh oleh2183@ukr.net; https://orcid.org/0000-0003-3351-9856

Краснов Володимир Павлович, д-р с.-г. наук, професор, кафедра екологіï. Email: volodkrasnov@gmail.com; https://orcid.org/0000-0003-1779-9544

Цитування за ДСТУ: Жуковський О. В., Краснов В. П. Формування соснового деревостану із збереженого підросту після рубки головного користування. Науковий вісник НлтУ України. 2021, т. 31, № 2. С. 46-51.

Citation APA: Zhukovskyi, O. V., \& Krasnov, V. P. (2021). Formation of pine stand from young growth preserved after clear-cutting. Scientific Bulletin of UNFU, 31(2), 46-51. https://doi.org/10.36930/40310207 
ня та вирощування лісових культур сосни звичайної [11]. Ці обставини знову актуалізували питання інтенсифікації переходу до створення соснових насаджень способом використання природного поновлення та впровадження технологій із збереження підросту сосни звичайної у період проведення суцільних рубок головного користування [6]. 3 огляду на це дослідження, спрямовані на вивчення способів збереження підросту сосни звичайної у процесі проведення суцільних рубок головного користування та встановлення закономірностей росту лісових культур, утворених після цього, є актуальними.

Об'єкт дослідження - соснові насадження, утворені 3 підросту сосни звичайної після суцільної рубки головного користування.

Предмет дослідження - стан і лісівничо-таксаційні характеристики соснових насаджень, утворених із підросту сосни звичайної після суцільних рубок головного користування із застосуванням заготівельної техніки.

Мета роботи - встановити стан та особливості росту 30-річних соснових деревостанів, утворених 3 підросту після суцільних рубок головного користування, проведених із збереженням природного поновлення.

Для досягнення зазначеної мети визначено такі основні завдання дослідження: вивчити та порівняти основні таксаційні показники деревостанів, створених після суцільних рубок головного користування на варіантах досліду; проаналізувати розподіл дерев за категоріями санітарного стану, якістю та класами Крафта; зробити узагальнення щодо стану деревостанів на варіантах досліду.

Наукова новизна отриманих результатів дослідження - вперше досліджено стан і продуктивність 30річних соснових насаджень, створених після суцільних рубок головного користування, проведених із застосуванням заготівельної техніки та зі збереженням природного поновлення.

Практична значущість результатів дослідження можна використати у практиці планування, організації та здійсненні суцільних рубок і лісовідновних заходів.

Аналіз останніх досліджень та публікацій. У середині XX ст. під час вибору системи господарювання у лісах перевагу почали надавати інтенсивному лісовому господарству, яке передбачало перехід від вибіркових до суцільних рубок і штучного лісовідновлення. Водночас, дослідники продовжувати вивчати успішність природного поновлення у різних типах лісорослинних умов і можливість його використання для створення продуктивних соснових деревостанів [13]. Відомо, що екологічний ареал сосни звичайної містить в собі значну кількість типів лісорослинних умов, які істотно відрізняються багатством і зволоженістю грунтів. Природно, що у різних екологічних умовах формуються різні за продуктивністю, структурою і рослинним різноманіттям фітоценози, в яких сосна звичайна $\epsilon$ едифікаторним видом. У природі процеси відновлення соснових насаджень, після досягнення стиглого віку, досить складні і частіше призводять до втрати сосною звичайного свого панівного положення. Так, частина білоруських дослідників, після тривалих досліджень, зазначала, що на всій території держави у соснових насадженнях триває незадовільне забезпечення природним поновленням сосни звичайної. Вони ж стверджували, що у бідних трофотопах переважає поновлення берези повислої, а у багатших - дуба звичайного (Quercus robur L.). Окрім цього білоруські науковці, вивчаючи рентабельність різних систем рубок, встановили, що високорентабельними $(52,0 \%) \epsilon$ несуцільні рубки із збереженням підросту [3]. Зворотною стороною впровадження несуцільних рубок, як стверджували науковці, $\epsilon$ значні втрати часу на їх проведення і потреба у кваліфікованих спеціалістах у всіх ланках лісогосподарського виробництва [9].

Такі обставини, про незадовільне природне поновлення сосни звичайної, також констатували й українські вчені і рекомендували штучне відтворення соснових деревостанів [4]. Дослідження, які були проведені у свіжих борах Київського Полісся, показали, що достатне природне поновлення $є$ на невеликій частині площ і що перевагу необхідно надати створенню лісових культур [7]. Схожі результати було отримано після вивчення природного поновлення сосни звичайної у різних типах лісорослинних умов Західного Полісся. На підставі них дослідники зробили висновок, що "У найбільш розповсюджених типах лісорослинних умов природне лісопоновлення на зрубах ослаблене, а під наметом материнських деревостанів - недостатнє. Частка пристигаючих, стиглих і перестійних соснових деревостанів 3 наявністю підросту у кількості, достатній для суцільного чи часткового лісовідновлення цієї породи, не перевищує 7,8\%" [17].

Відомо, що під час проведення суцільно-лісосічних рубок здебільшого відбувається знищення наявного під наметом лісу підросту, а наступні технології створення та вирощування лісових культур довершують цей процес. За останні десятиліття XX ст. у частині лісгоспів Полісся України суцільні рубки головного користування проводили за допомогою комплексу машин, до складу якого входили валильно-пакетувальна машина ЛП19А, безчокерний трелювальник ЛТ-154 та сучкорізна машина ЛП-33. Вважали, що використання різноманітної заготівельної техніки під час проведення рубок головного користування буде розширюватися. Тому у 1986-1989 рр. у лісових насадженнях Житомирської області розпочали дослідження з розроблення лісосік сосни звичайної методом вузьких пасік на базі зазначеної вище техніки. Отримані результати дали змогу дослідникам підтвердити припущення про високу збереженість підросту головних деревних порід на рівні 7082 \%. Науковці також стверджували, що відзначену валильно-пакетувальну машину можна використовувати для різних способів рубки: суцільно-лісосічних, рівномірно-поступових та добровільно-вибіркових. Треба зазначити, що в Україні все ж таки існує певний досвід проведення суцільних рубок головного користування, які забезпечують збереження підросту [2], але достатнього поширення у практиці ведення лісового господарства він не набув.

У Російській Федерації випробовували різні схеми розроблення лісосік валильно-пакетувальними машинами із збереженням підросту на базі ЛП-19+ЛТ$154+$ ЛП-33. За однієї із схем характерною рисою технологічного процесу було залишення на лісосіці "відбійних" дерев (його рекомендують застосовувати на особливо захисних ділянках лісу). Згідно з другою схемою, розробку лісосіки проведено із прокладанням двох магістральних волоків та паралельних лісових ву- 
сів машиною ЛП-19, пакетування дерев відбувалося на волоці, відповідно по них і магістральних волоках трелювали пачки дерев до навантажувального майданчика. Дослідження продемонстрували, що за обох схем розроблення лісосік можна отримати високе збереження природного поновлення [10]. На підставі проведених досліджень створено "Инструкцию по сохранению подроста и молодняка хозяйственно ценных пород при разработке лесосек и приемке от лесозаготовителей вырубок с проведёнными мероприятиями по восстановлению леса" [5].

Аналіз літературних джерел свідчать про неоднозначність отриманих результатів і ставлення науковців до проблеми відновлення соснових насаджень способом використання природного поновлення. Водночас, зважаючи на необхідність розроблення наукових основ використання природного відновлення соснових деревостанів, проведення досліджень зі збереження підросту сосни звичайної та вивчення закономірностей подальшого формування насаджень цієї деревної породи після суцільних рубках головного користування із застосуванням заготівельної техніки є важливим і актуальним напрямом лісівничих досліджень.

Матеріали та методи дослідження. Дослідження проводили на стаціонарному досліді № 8, який закладено у 1988 р. у виділі 16/22, квартал 39 Кропивнянського лісництва ДП "Коростишівське ЛГ" Житомирської області (географічні координати: 50¹5'51.4" північної широти, 29¹1'25,9" східної довготи). Таксаційна харак-

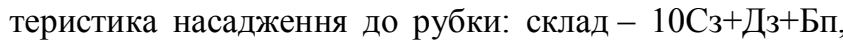
вік - 80 років, $D_{c p}=28 \mathrm{~cm}, H_{c p}=23 \mathrm{м}$, повнота - 0,7 , клас бонітету - II, запас $-280 \mathrm{~m}^{3} \cdot \mathrm{ra}^{-1}$, тип лісорослинних умов - бідний підтип свіжого субору. На ділянці до рубки під наметом материнського деревостану був наявний густий, рівномірно розподілений на площі підріст сосни звичайної віком 3-7 років - 22000 шт. га $^{-1}$.

Ділянку розділено на дві секції. На першій виконали вузько пасічну заготівлю деревини з використанням таких машин: для звалювання дерев - ЛП-19А, обрубування сучків - ЛП-33, трелювання деревини - ЛТ-171 і iii навантаження - ЛТ-25. Ширина пасік становила 15 м. На другій секції (контроль) заготівлю і трелювання звалених дерев проводили без нарізування пасік та регламентування обов'язкового руху лісозаготівельних машин волоками. Далі на другій секції, на якій наявний підріст був практично повністю знищений, було створено лісові культури посадкою у борозни сіянців сосни звичайної та дуба звичайного за схемою: 4 ряди сосни, 1 ряд дуба, з відстанню між рядами - 2 м, в ряду0,7 м. У культурах перші три роки здійснювали агротехнічний догляд, а у 1997 р. проведено освітлення.

На першій секції після проведення суцільної лісовідновної рубки велика кількість підросту сосни звичайної загинула. Основними причинами загибелі соснового підросту були: відмирання нежиттєздатних особин внаслідок різкого освітлення та враження великим сосновим довгоносиком (Hylobius abietis (C. Linnaeus, 1758). У 1994 р. після проведених проміжних досліджень встановлено, що на цій частині ділянки сформований сосновий деревостан природного походження 3 домішкою берези повислої і дуба звичайного. У 20112012 pр. на обох варіантах досліду проведено прорідження $з$ вибіркою супутніх порід і відсталих у рості дерев сосни звичайної.
У 2018 р. (через 30 років від часу закладання досліду) на його варіантах було досліджено стан наявних деревостанів. Закладання пробних площ було здійснено у межах кожної із секцій відповідно до загальноприйнятих методик $[1,14]$ та згідно з СОУ 02.02-37-476:2006 "Площі пробні лісовпорядні. Метод закладання" [15]. На пробних площах, розмір яких забезпечував наявність не менше 200 стовбурів головної породи, здійснювали заміри діаметрів (точність $0,1 \mathrm{~cm}$ ) за допомогою мірної вилки, у 30 модельних дерев вимірювали висоти за допомогою висотоміра ВКН-1. Окомірно, згідно з відповідними шкалами, встановлювали для кожного дерева клас Крафта, категорію санітарного стану та якості. Для вивчення диференціації дерев у насадженнях застосовували розподіли дерев окремих порід за природними ступенями товщини, класами Крафта, категоріями санітарного стану та якості. Санітарний стан насаджень встановлювали за індексом санітарного стану згідно із Санітарними правилами в лісах України $[1,14,16]$.

\section{Результати дослідження та їх обговорення}

На час досліджень, які були проведені у 2018 р., вік деревостану на секціях досліду становив: на контролі (лісові культури) 28 років, на секції із збереженням підросту - 33 роки (табл. 1). За складом соснові деревостани майже не відрізняються, на варіанті зі створенням соснових культур увели дуб звичайний, але сьогодні екземпляри цієї деревної породи трапляються лише поодиноко і відповідають деревам III-V класів росту. На варіанті із збереженням підросту до складу деревостану разом із сосною звичайною входять у невеликих кількостях береза повисла і вільха чорна (Alnus glutinosa (L.) Gaertn).

Табл. 1. Лісівничо-таксаційна характеристика соснових деревостанів на стаціонарному досліді № 8 станом на 2018 р.

\begin{tabular}{|c|c|c|c|c|c|c|}
\hline Склад & $\begin{array}{l}\text { Вік, } \\
\text { ро- } \\
\text { ків }\end{array}$ & $\begin{array}{l}\text { Густота, } \\
\text { шт } \cdot{ }^{-1}\end{array}$ & $\begin{array}{l}\text { Клас бо- } \\
\text { нітету/ } \\
\text { повнота }\end{array}$ & $\begin{array}{l}\text { Площа попе- } \\
\text { речного пере- } \\
\text { різу, } \text { м }^{2} \cdot \text { ra }^{-1}\end{array}$ & $\begin{array}{c}\text { Об'єм } \\
\text { дерева, } \\
\text { м }^{3}\end{array}$ & $\begin{array}{l}\text { Запас, } \\
\mathrm{m}^{3} \cdot \mathrm{ra}^{-1}\end{array}$ \\
\hline \multicolumn{7}{|c|}{ Варіант із створенням соснових культур } \\
\hline $\begin{array}{c}10 \mathrm{C}_{3}+ \\
\text { Д3 }\end{array}$ & 28 & 2388 & $\mathrm{I} / 1,0$ & 33,8 & 0,086 & 205 \\
\hline \multicolumn{7}{|c|}{ Варіант із збереженням підросту сосни звичайної } \\
\hline $\begin{array}{l}10 \mathrm{C}_{3}+Б \\
\Pi+\text { Влч }\end{array}$ & 33 & 2000 & $\mathrm{I}^{\mathrm{a}} / 1,0$ & 35,8 & 0,128 & 255 \\
\hline
\end{tabular}

Старшим є сосновий деревостан, створений із природного поновлення. Різниця між ними становить 5 років, але ця різниця не перевищує одного класу віку. За повнотою і класом бонітету у соснових деревостанах різниці немає. Спостерігаються відмінності між величинами площі поперечного перерізу, об'єму одного дерева і запасу. Наведені вище показники є більшими на варіанті із збереженням соснового підросту: за площею поперечного перерізу - на 5,6 \%, об'ємом одного дерева на $32,8 \%$ і запасом деревини - на 19,6\%.

Величина середнього діаметра є більшою (на $14 \%$ ) на варіанті із збереженням підросту (табл. 2). Достовірність різниці підтверджується однофакторним дисперсійним аналіз під час порівняння значень діаметрів між варіантами 3 різними способами лісовідновлення, де $F_{\phi}=18,35>F_{m(0,95)}=3,86, p=0,00002$.

Для виявлення відмінностей у формуванні соснових деревостанів проведемо розподіл дерев на варіантах досліду за ступенями товщини. Виявлено, що на варіанті лісових культур крива розподілу має: декілька вер- 
шин, значний розмах у діапазоні 0,3-2,0 ступенів товщини, правосторонню асиметрію із значенням близьким до нуля і виражений ексцес в діапазоні 1,0-1,1 ступенів товщини (див. табл. 2, рис. 1). Дані розподілу дерев за ступенями товщини на варіанті зі створенням культур вказують, що у насаджені відбуваються інтенсивні процеси внутрішньовидової конкуренції і диференціації дерев за класами росту.

Табл. 2. Статистика ряду розподілу діаметрів соснових деревостанів на варіантах стаціонарного досліду № 8

\begin{tabular}{|c|c|c|c|c|c|}
\hline $\begin{array}{c}\text { Середній } \\
\text { діаметр, } \\
\text { см }\end{array}$ & $\begin{array}{c}\text { Максималь- } \\
\text { ний ді- } \\
\text { аметр, см }\end{array}$ & $\begin{array}{c}\text { Мінімаль- } \\
\text { ний ді- } \\
\text { аметр, см }\end{array}$ & $\begin{array}{c}\text { Стандар- } \\
\text { тне від- } \\
\text { хилення }\end{array}$ & Ексцес & $\begin{array}{c}\text { Аси- } \\
\text { метрія }\end{array}$ \\
\hline \multicolumn{5}{|c|}{ Варіант із створенням соснових культур } \\
\hline $12,6^{ \pm 0,32}$ & 26,0 & 4,0 & $\pm 4,6$ & $-0,36$ & 0,04 \\
\hline \multicolumn{5}{|c|}{ Варіант із збереженням підросту сосни звичайної } \\
\hline $14,5^{ \pm 0,31}$ & 26,5 & 5,0 & $\pm 4,3$ & $-0,10$ & 0,25 \\
\hline
\end{tabular}

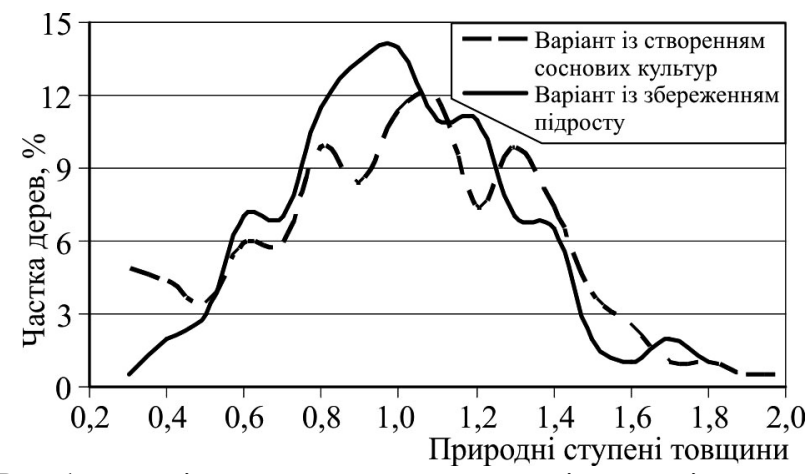

Рис. 1. Розподіл дерев соснових деревостанів на стаціонарному досліді № 8 за природними ступенями товщини

Дещо інша ситуація з розподілом дерев за ступенями товщини на варіанті із збереженням підросту: крива розподілу дерев $\epsilon$ одновершинною 3 правосторонньою асиметрією значень; сторони є плавними, розмах значень знаходиться у діапазоні 0,3-1,8 ступенів товщини; виражений ексцес в діапазоні 0,9-1,0 ступенів товщини. Цей розподіл вказує на те, що процеси внутрішньовидової конкуренції і диференціація дерев за класами росту на варіанті із збереженням підросту відбувається менш активно. Останнє, напевно, вказує, що цей процес відбувався активніше у попередні роки.

Середня висота насаджень є більшою на $18 \%$ на варіанті із збереженням підросту (табл. 3). Достовірність різниці підтверджується результатами однофакторного дисперсійного аналізу, де $F_{\phi}=71,92>F_{m(0,95)}=4,00$, $p=0,0000001$.

Табл. 3. Статистика ряду розподілу середніх висот соснових деревостанів на варіантах стаціонарного досліду № 8

\begin{tabular}{|c|c|c|c|c|c|}
\hline $\begin{array}{c}\text { Середня } \\
\text { висота, м }\end{array}$ & $\begin{array}{c}\text { Максималь- } \\
\text { на висота, м }\end{array}$ & $\begin{array}{c}\text { Мінімальна } \\
\text { висота, м }\end{array}$ & $\begin{array}{c}\text { Стандар- } \\
\text { тне від- } \\
\text { хилення }\end{array}$ & $\begin{array}{c}\text { Ек- } \\
\text { сцес }\end{array}$ & $\begin{array}{c}\text { Аси- } \\
\text { метрія }\end{array}$ \\
\hline \multicolumn{5}{|c|}{ Варіант із створенням соснових культур } \\
\hline $11,2^{ \pm 0,18}$ & 12,6 & 7,5 & $\pm 1,00$ & 5,10 & $-1,60$ \\
\hline \multicolumn{7}{|c|}{ Варіант із збереженням підросту сосни звичайної } \\
\hline $13,3^{ \pm 0,18}$ & 15,1 & 11,0 & $\pm 0,96$ & $-0,07$ & $-0,20$ \\
\hline
\end{tabular}

Побудовані криві висот демонструють, що показники росту за висотою є вищими для варіанта із збереженням підросту. При цьому крива на цьому варіанті $\epsilon$ значно зміщена в бік більших ступенів товщини, тоді як деревостан на варіанті зі створенням соснових культур відстає у рості і за висотою, і за діаметром (рис. 2).

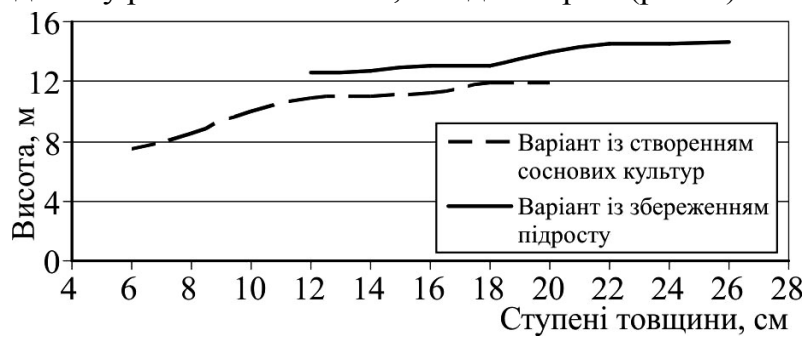

Рис. 2. Криві висот соснових деревостанів на варіантах стаціонарного досліду № 8

Відмінності у рості насаджень виявлено і під час аналізу розподілу дерев за категоріями санітарного стану, якості та класами Крафта (табл. 4). Так, основна частка дерев належить до III-IV категорій санітарного стану: $65 \%$ - на варіанті із збереженням підросту та $49 \%$ - на варіанті із створенням соснових культур. Найбільша кількість здорових дерев трапляється у варіанті із збереженням підросту, де їх частка становить $9 \%$. На варіанті із створенням соснових культур виявлено найбільшу кількість свіжого і старого сухостою $12 \%$. За індексом санітарного стану ці насадження належать до сильно ослаблених. За розподілом дерев за класами встановлено, що частка дерев I та V класів Крафта $є$ більшою у варіанті із створенням соснових культур (відповідно 31 і 14 \%), тоді як у варіанті із збереженням підросту - 20 і $5 \%$, відповідно. Середній клас Крафта для обох насаджень є однаковим - 2,4.

Табл. 4. Розподіл дерев за індексами санітарного стану, класами Крафта і категоріями якості соснових деревостанів у варіантах стаціонарного досліду №8

\begin{tabular}{|c|c|c|c|c|c|c|c|}
\hline \multicolumn{2}{|c|}{$\begin{array}{c}\text { Розподіл дерев за категоріями } \\
\text { санітарного стану, \% }\end{array}$} & \multirow{2}{*}{$\begin{array}{l}\text { Індекс санітарного } \\
\text { стану насадження }\end{array}$} & \multicolumn{2}{|c|}{$\begin{array}{c}\text { Розподіл дерев за класа- } \\
\text { ми Крафта, \% } \\
\end{array}$} & \multirow{2}{*}{$\begin{array}{c}\text { Середній клас } \\
\text { Крафта насадження }\end{array}$} & \multicolumn{2}{|c|}{$\begin{array}{c}\text { Розподіл дерев за категорі- } \\
\text { ями якості, \% } \\
\end{array}$} \\
\hline I-IV & V-VI & & I-III & IV-V & & ділові & дров'яні \\
\hline \multicolumn{8}{|c|}{ Варіант із створенням соснових культур } \\
\hline 86 & 14 & 3,1 & 80 & 20 & 2,4 & 3 & 97 \\
\hline \multicolumn{8}{|c|}{ Варіант із збереженням підросту сосни звичайної } \\
\hline 95 & 5 & 2,8 & 86 & 14 & 2,4 & 20 & 80 \\
\hline
\end{tabular}

Під час аналізу розподілу дерев за категоріями якості встановлено, що в обох насадженнях переважає дров'яна деревина. У варіанті із створенням соснових культур часка дерев III категорії якості становить $97 \%$, тоді як у варіанті із збереженням підросту вона $\epsilon$ меншою на 17 \%. Частка дерев I категорії якості є більшою у варіанті із збереженням підросту $-20 \%$.

Одним $з$ показників, який характеризує стан деревостану, $є$ очищення стовбура від сучків. Результати дослідження вказують, що у варіанті із збереженням підросту є кращі показники (рис. 4). Так, довжина відрізка стовбура, який повністю очищений від сучків, у варіанті із збереженням підросту становить 2,6 м, а у варіанті із створенням соснових культур - 0,4 м (у 6,5 раза менше). Частина стовбура із сухими гілками у варіанті із збереженням підросту становить 6,6 м, а у варіанті із створенням соснових культур - 6,4 м. Частина стовбура із живою кроною у варіанті із збереженням підросту становить $4,1 \mathrm{M}$, а із створенням соснових культур - 4,4 м. 
Співвідношення між частинами стовбура - довжина стовбура, очищена від сучків, довжина стовбура із сухими сучками і довжина стовбура із живими гілками для варіанта із збереженням підросту становить відповідно 20, 50, 30 \%, а для варіанта із створенням соснових культур - 4, 57, $39 \%$.

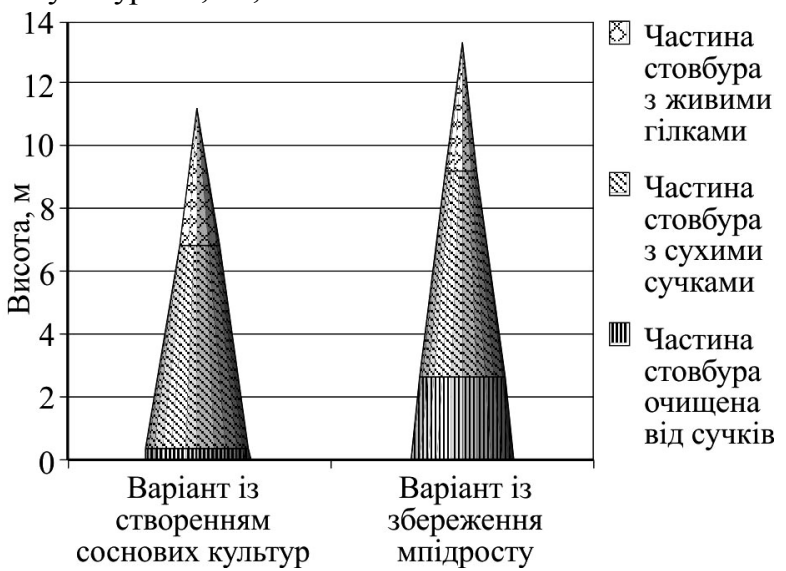

Рис. 3. Очищеність стовбурів дерев від сучків у варіантах стаціонарного досліду № 8

\section{Висновки}

Проведення суцільних рубок головного користування з використанням сучасних валильних машин шляхом вузько пасічної заготівлі деревини дає змогу зберегти достатню кількість підросту сосни звичайної для формування продуктивного деревостану. Застосування подібних технологій сприяє пришвидшенню терміну відновлення лісових насаджень, ніж це відбувається шляхом створення лісових культур (на 5 років). Деревостан, що сформувався із підросту сосни звичайної, має кращі таксаційні характеристики, ніж лісові культури, створені після вирубування стиглого деревостану: середній діаметр - на $14 \%$, середня висота - на $18 \%$. Водночас, враховуючи різницю між віком штучних і відновлених 3 підросту деревостанів - 5 років, можна стверджувати, що відзначені відмінності значно менші.

\section{References}

1. Anuchin, N. P. (1982). Lesnaia taksatciia. Moscow: Lesnaia promyshlennost. [In Russian].

2. Buzun, V. O., \& Prystupa, H. K. (1989). Mashyna LP-19A i lisovidnovlennia. Forestry, Forest, Paper and Woodworking Industry, 2, 17-18. [In Ukrainian].

3. Gordei, N. V., Skrigalovskaia, V. A., \& Kozlov, A. K. (2004). Estestvennoe vozobnovlenie v sosnovykh nasazhdeniiakh Belarusi. Problemy lesovedeniia $i$ lesovodstva na radioaktivno zagriaznennykh zemliakh, 60, 44-52. [In Russian].

4. Gordienko, M. N., Shablii, M. V., \& Shlapak, V. P. (1995). Sosna obyknovennaia, ee osobennosti, sozdanie kultur, proizvoditelnost. Kiev: Lybid, 168 p. [In Russian].

5. Gosleskhoz SSSR. (1984). Instruktciia po sokhraneniiu podrosta $i$ molodniaka khoziaistvenno tcennykh porod pri razrabotke lesosek $i$ priemke ot lesozagotovitelei vyrubok s provedennymi meropriiatiiami po vosstanovleniiu lesa. Moscow, 320 p. Retrieved from: http://www.libussr.ru/doc_ussr/usr_11846.htm. [In Russian].

6. Grib, V. M., \& Ishhik, A. A. (2012). Prirodne ponovlennia sosni na zrubakh. Scientific Bulletin of UNFU, 22(4), 72-77. Retrieved from: https://nv.nltu.edu.ua/Archive/2012/22 4/index.htm. [In Russian].

7. Holovetskyi, M. P. (2001). Pryrodne ponovlennia u borakh Kyivskoho Polissia. Ahrarna nauka i osvita, 2(1-2), 100-106. [In Ukrainian].

8. Ketov, V. Ia., \& Popov, A. V. (1992). Sokhranenie podrosta na pasekakh pri mekhanizirovannoi zagotovke drevesiny. Lesoekspluatatciia i lesosplav, 1, 1-2. [In Russian].

9. Kozhevnikov, A. M., \& Feofilov, V. A. (1969). Postepennye $i$ vyborochnye rubki v lesakh Belorusii. Minsk: Urozhai, 260 p. [In Russian].

10. Krasnov, V. P., Vedmid, M. M., Orlov, O. O. (2009). Atlas roslyn-indykatoriv i typiv lisoroslynnykh umov Ukrainskoho Polissia. Novohrad-Volynskyi: Novohrad. [In Ukrainian].

11. Meshkova, V. L. (2019). Usykhanie sosnovykh lesov Ukrainy s uchastiem koroedov: prichiny i tendentcii. Izvestiia Sankt-Peterburgskoi lesotekhnicheskoi akademii, 228, 312-335. https://doi.org/10.21266/2079-4304.2019.228.312-335. [In Russian].

12. Mieshkova, V. L. (2008). Zminy parametriv spalakhiv masovoho rozmnozhennia komakh-khvoielystohryziv za ostanni 30 rokiv. Forestry and agroforestry, 113, 265-273. Retrieved from: https://core.ac.uk/download/pdf/38344963.pdf. [In Ukrainian].

13. Nakonechnyi, V. S., \& Sviridenko, V. E. (1972). Opyt postepennykh rubok v Boiarskom uchebno-opytnom leskhoze $\mathrm{i}$ ispolzovanie ego v uchebnykh tceliakh. Nauchnye trudy USKhA, 65, 26-29. [In Russian].

14. Pasternaka, P. S., et. al. (1990). Spravochnik lesovoda. Kiev: Urozhai. [In Russian].

15. Ploshchi probni lisovporiadni. Metod zakladannia: SOU 02.0237-476: 2006 (2007). Chynnyi vid 2007. Kyiv, Minahropolityky Ukrainy. [In Ukrainian].

16. Sanitarni pravyla v lisakh Ukrainy: 756-2016-p (2016). Chynnyi vid 11.11.2016. Kyiv, KMU. Retrieved from; https://zakon.rada.gov.ua/laws/show/756-2016-\%D0\%BF\#Text. [In Ukrainian].

17. Vedmid, M. M., Shkudor, V. D., \& Buzun, V. O. (2008). Vidnovlennia pryrodnykh lisostaniv Zakhidnoho Polissia. Zhytomyr: Polissia. [In Ukrainian].

18. Zhukovskyi, O. V., Orlov, O. O., Zborovska, O. V., Strutynskyi, O. V., SHevchuk, V. V., Karchevskyi, R. A., Hulyk, I. T., \& Levkivskyi, O. V. (2018). Sanitarnyi stan sosnovykh derevostaniv pislia provedennia sanitarnykh rubok vybirkovykh, $\mathrm{u}$ kulisakh ta dribnokonturnykh diliankakh v oseredkakh urazhennia koroidom verkhivkovym. Scientific Bulletin of UNFU, 28(8), 87-91. https://doi.org/10.15421/40280818

O. V. Zhukovskyi', V. P. Krasnov

${ }^{1}$ Polisky Branch of Ukrainian Research Institute of Forestry and Forest Melioration named after G. M. Vysotsky, Zhytomyr, Ukraine ${ }^{2}$ Zhytomyr Polytechnic State University, Zhytomyr, Ukraine

\section{FORMATION OF PINE STAND FROM YOUNG GROWTH PRESERVED AFTER CLEAR-CUTTING}

The literature review indicates the ambiguity of the obtained results on the problem of restoration of pine stands by natural regeneration, which, in turn, indicates the importance of the research for developing a scientific basis for stand restoration after clear-cutting with application of harvesting equipment. The research was performed on a stationary experiment laid in 1988 in a mature pine stand with a sufficient amount (22.000 pieces-ha-1) of young growth of the main species. In half of the experimental plot, clear-cutting was carried out using felling machines through narrow forest rides. The second part of the plot was developed by the traditional method followed by the creation of Scots pine crops on it. Trial plots were laid out within each of the sections in accordance with generally accepted methods in silviculture, forestry and forest assessment. Stand age in the experimental sections is as follows: forest crops (control) - 28 years, in the sections with the preservation of young growth -33 years. There is no difference in completeness and productivity index in pine stands. It was found that in the variant with the preservation of pine young growth, the cross-sectional 
area is greater by $5.6 \%$, the volume of one tree - by $32.8 \%$, the average diameter - by $14.0 \%$, the average height - by $18.0 \%$, and wood stock - by $19.6 \%$. Data on the distribution of trees by degrees of thickness indicates that intensive processes of intraspecific competition and differentiation of trees by Kraft classes take place in the stand variant with the creation of crops, although these processes are found to be less active in the stand variant with the preservation of young growth. Most healthy trees occur in the variant with the preservation of young growth, where their share is $9 \%$, and fresh and old snag in the variant with the creation of pine crops accounts for $12 \%$. According to the sanitary condition index, these stands are severely weakened. Considering the distribution of trees by quality categories, firewood is predominant in these stands. Carrying out felling with the use of young growth conservation technologies enables speeding up the recovery period of forest plants more than by creating forest crops (for 5-year period).

Keywords: Scotch pine; diameter; height; stock; sanitary condition. 